ーノートー

固相マイクロ抽出法および溶媒抽出法を用いた生長段階別の大麻成分の分析

\author{
久土智也，木口昭夫，藤井広志* \\ 厚生労働省九州厚生局麻薬取締部 \\ 干812-0013 福岡市博多区博多駅東 2-10-7 福岡第二合同庁舎 1 階
}

\title{
Analysis of cannabis components by growth stage using solid-phase microextraction and solvent extraction
}

\author{
Tomoya Kudo, Akio Kiguchi and Hiroshi Fujii* \\ Narcotics Control Department, Kyushu Regional Bureau of Health and Welfare, \\ Ministry of Health, Labour and Welfare \\ 2-10-7, Hakataeki-Higashi, Hakata-ku, Fukuoka, 812-0013, Japan
}

(Received 25 December 2018; accepted 27 April 2019;

Published online 14 June 2019 in J-STAGE DOI: 10.3408/jafst.758)

Illegal distribution of cannabis products, such as cannabis-infused foods and eliquids, are increasing in Japan. The main component of cannabis is tetrahydrocannabinol (THC). THC extracted from cannabis is regulated by the Cannabis Control Act, and chemically synthesized THC is regulated by the Narcotics and Psychotropics Control Act; therefore, it is important to identify the source of THC for judicial appraisal. Recently, the crime of cultivating cannabis has occurred frequently in Japan. Illegal cultivation is difficult to discover because there are cases in which cannabis is cultivated secretly in a room in apartments, etc. Cannabis is a plant that emits unique odors. Detection of the odor constituents can provide a breakthrough for the criminal investigation of cannabis cultivation. The purpose of this study was to identify cannabis products and utilize them for the criminal investigation of cannabis cultivation. Cannabis plants were cultivated from seeds and analyzed using both solid-phase microextraction (SPME) and solvent extraction. Fifty kinds of volatile components were detected by SPME and 21 kinds of refractory components were detected by solvent extraction in fresh cannabis plants. We found that terpenes were detected more strongly in cannabis buds than in cannabis leaves. Furthermore, sesquiterpenes were strongly detected from cannabis leaves and monoterpenes were strongly detected from cannabis buds. The most abundant components were $\beta$-myrcene, cis- $\beta$-ocimene, terpinolene, $\beta$-caryophyllene, trans $-\alpha$-bergamotene, humu-

現所属 : 厚生労働省近畿厚生局麻薬取締部

干 541-8556 大阪市中央区大手前 4-1-76 大阪合同庁舎第 4 号館 3 階

Narcotics Control Department, Kinki Regional Bureau of Health and Welfare, Ministry of Health, Labour and Welfare

4-1-76, Otemae, Chuo-ku, Osaka, 541-8556, Japan 
lene and $\beta$-farnesene. Additionally, THC, cannabichromene, cannabigerol and tetrahydrocannabivarin known as cannabinoids, were detected in all the samples. For the identification of cannabis products, 7 kinds of terpenes and 4 kinds of cannabinoids are promising combinations. Additionally, these terpenes may be useful in the criminal investigation of cannabis cultivation.

\section{Key words: Cannabis product, SPME, Terpene, Cannabinoid}

日本国内において，大麻を含有する食品や e-リ キッドなどの大麻製品が不正に流通している. 大麻 の主成分は，テトラヒドロカンナビノール（THC） である。大麻由来の THC は大麻取締法によって規 制されており，化学合成された THC は麻薬及び向 精神薬取締法によって規制されているため, 司法鑑 定上 THC の由来源の特定は重要である. 近年, 日 本では大麻栽培事犯が頻発している. 大麻はマンシ ヨン等の一室で秘密裏に栽培されるため, 不正栽培 の発見は難しい. 大麻は特徵的なにおいを発する植 物であり，そのに拈い成分の検知が大麻栽培事犯の 捜査の突破口となり得る。本研究では, 大麻製品の 同定抢よび大麻栽培事犯の捜査に活用できる有効な 成分を探索することを目的とした．大麻草は種子か ら栽培し, 固相マイクロ抽出 (SPME) 法および溶 媒抽出法を用いて分析した. 新鮮な大麻草から50種 類の揮発性成分をSPME 法で検出し，21種類の難 揮発性成分を溶媒抽出法で検出した．大麻の葉より も花穂の方からテルペンが強く検出されることが明 らかになった.さらに, 大麻の葉からはセスキテル ペン, 花穂からはモノテルペンが強く検出された。 最も検出強度が高かった成分は, $\beta$-Myrcene, cis- $\beta-$ Ocimene, Terpinolene, $\beta$-Caryophyllene, trans $-\alpha-$ Bergamotene, Humulene および $\beta$-Farnesene であっ た。さらに，カンナビノイドとして知られる $\mathrm{THC}$, カンナビクロメン, カンナビゲロールおよ びテトラヒドロカンナビバリンは全ての検体から検 出された. 7 種類のテルペンおよび 4 種類のカンナ ビノイドが大麻製品の同定において有望な組反合わ せであると考えられた．また，これらのテルペンは 大麻栽培事犯の捜査へ応用できる可能性があると考 えられた。

\section{緒 言}

近年, 世界で最も乱用されている薬物は大麻およ びその製品であり，その乱用は世界規模で広がって いる. 従来の大麻の鑑定は, $\mathrm{THC}$ 等の検出々, 形 態学的特徵の検查（剛毛および腺毛などの検出）に よって行っているが，これらの大麻製品の場合，形 態学的特徵が見つかりにくいため, 鑑定上での大麻 取締法違反の立証に支障をきたしているところであ る. その理由の一つとして, THCの合成品は, 大 麻取締法とは別の法律である麻薬及び向精神薬取締 法で規制されていることから，これと大麻製品を識 別する必要があることが挙げられる.

また，日本国内に抢ける近年の傾向として，倉庫 やマンションの一室を借り切って, 大規模に大麻栽 培を敢行している事例が頻発している，大麻は，覚 せい剤と違い, 密輸を介さずに入手ができ, 増殖さ せることもできるため，潜在的に増加しているおそ れがある1).

大麻は他の違法薬物と比較して，に拈いが強く特 徵的であり, マンションの一室から異臭がするとの 通報が端緒となり大麻栽培事犯の捜査に至った事例 が存在する，大麻のに拈い成分のほとんどがテルペ ンの一種であるモノテルペン抢よびセスキテルペン から構成されている。税関に抢いては麻薬探知犬を 用いたに括い検知による探索が行われ，それを補助 するためのに拉い゙イオセンサーの開発も行われて いる. 麻薬探知犬の大麻探知マーカーは, セスキテ ルペンの Caryophyllene oxideであると報告2)され ているが，揮発性成分の分析からに扔い゙イオセン サーのターゲットの候補としてはモノテルペンの Terpinolene, Fenchone, endo-Fenchol, trans-2Pinanol, Borneol および $\alpha$-Terpineol のうち, 4〜6 化合物の組み合わせが有望であると報告3)されてい 
る.さらに，大麻およびその他関連植物の揮発性成 分を分析した結果から大麻に特徵的な化合物はセス キテルペンの $\alpha$-Santalene, Valencene 抢よび $\beta$-Bisaboleneであると報告4)されている。しかし，既 報4-6)によれば，Terpinolene を除く，上記10種類の 化合物は大麻中にごく微量しか含有されていないた め，大麻製品の鑑定および大麻栽培事犯の捜査に供 するには困難が生じる.

大麻揮発性成分の分析方法には，ガスタイトシリ ンジ3,5)やヘッドスペースー固相マイクロ抽出 $(\mathrm{SPME})^{7)}$ などを用いたヘッドスペース法, 大麻精 油を直接分析する方法 $5,9,10)$ もくはアルコールな ぞの溶媒により抽出してから分析する溶媒抽出 法8,11) が用いられるが，大麻精油の気相と液相中の 成分組成は一致しないことが報告5)されている。こ の事実は，分析方法の違いによって得られる結果が 一致するとは限らないことを示している.ヘッドス ペース法は人や動物が臭気として感じる成分組成の 評価だけでなく，食品やオイルなどのあらゆる形態 が想定される大麻製品の高感度スクリーニング分析 として最適な手段となり得る。また，揮発性成分を 対象とした大麻栽培事犯の捜査に応用するにはへッ ドスペース法が適していると考えられるが，ヘッド スペース法を用いた採取直後の新鮮な大麻の揮発性 成分を分析した報告はない。

大麻には, $\mathrm{THC}$ や揮発性成分の他, 複数のカン ナビノイドが含まれて抢り，Cannabinol (CBN)， Cannabidiol (CBD), Cannabigerol (CBG), Cannabichromene ( $\mathrm{CBC})$, Tetrahydrocannabivarin (THCV) およびそれらのアシッド体は大麻植物に 特有な成分として知られている. 生長過程にある大 麻草中のカンナビノイドを経時的かつ部位別に調べ た報告例は少ない11).

本研究では，大麻草中に含まれる揮発性成分抢よ びカンナビノイドに着目し，大麻製品の同定抢よび 大麻栽培事犯の捜査に利用できる対象成分を探索す ることを目的として検討を行った。

\section{1. 実験材料}

\section{材料および方法}

\section{1. 分析対象}

大麻研究者免許を得て, 厚生労働省九州厚生局麻 薬取締部鑑定室において, 大麻種子から大麻草を栽 培し，生育した大麻草23株を分析対象とした。な お, 大麻種子は, 国庫帰属大麻を厚生労働大臣加 譲り受け, 大麻に混入していたものを使用した. 国 庫帰属大麻は, 捜査で押収され, 裁判で没収とな り，国庫に帰属されたものである。

\section{2. 試薬}

抽出に用いたメタノールは市販の特級試薬を使用 した．検出ピークの同定には以下の標準品を使用し た. $\alpha$-Pinene, $\beta$-Pinene, $\beta$-Myrcene, 3 -Carene, $\mathrm{p}-$ Cymene, $\alpha$-Terpinene, (D)-Limonene, Eucalyptol, $\gamma$-Terpinene, Terpinolene, Linalool, Fenchol, $\alpha$-Terpineol, $\beta$-Caryophyllene, Humulene, $\beta$-Bisabolene は東京化成, Camphene, $\alpha$-Phellandrene は関東化 学, $\beta$-Ocimene (cis \& trans) はシグマアルドリッ チから入手した.

\section{3. 器具}

マニュアル用 SPME ホルダー, SPMEファイ バーアセンブリー（膜厚 $100 \mu \mathrm{m}$ polydimethylsiloxane), SPME インレットガイド, $20 \mathrm{~mL}$ 容ク リンプトップバイアル，セプタム付きクリンプキャ ップは全て SUPELCO 製を使用した。なお，クリ ンプトップバイアルは事前に AquaSil Siliconizing Fluid（Thermo Scientific 製）でシリコンコーティ ングを施したものを使用した。

\section{2. 栽培条件}

大麻種子 32 粒を 1 粒ずつロックウール（Grodan 社製）に播種し，毎日水を与えた。㦳培開始後11日 から21日目までの間に23粒が発芽した。21日目以降 は，発芽した23株について栄養剤の投与を開始し た. 栄養剤の種類や投与量, 投与間隔の設定には, 書籍「マリファナ・X $\rfloor^{12}$ を参照した。生長期に該 当する栽培開始後 5 日目から55日目にかけては, 青 色光（HG-STRONG BLUE，世界貿易株式会社製) を24時間持続照射した. 開花期および成熟期に該当 する栽培開始後56日目から133日目までは, 赤色光 
（HG-STRONG RED，世界貿易株式会社製）の照 射および非照射を12時間毎に繰り返し行った. 栽培 開始後56日目（day56）前後約 1 週間に雄花抒よび 花穂の生成開始, 栽培開始後112日目（day112）前 後約 1 週間に種子の生成開始を確認した. 栽培した 大麻草は, 雄株が 1 株, 雌株が 19 株, 残り 3 株は栽 培開始後14日目（day14）に分析対象とし，それ以 降生長しなかったため雌雄判別が不能であった. 雌 雄の識別は，栽培開始後70日目（day70）に行い, いずれも分析対象とした。

\section{3. 前処理方法}

\subsection{SPME 法}

大麻草中の揮発性成分の検出のため, 前処理方法 として，以下に示す SPME 法を用いた。

大麻草の葉または花穂を採取し，はさみで細かく 刻み， $50 \mathrm{mg}$ （秤量䛊差 5 \% 以内）をそれぞれ 20 $\mathrm{mL}$ 容クリンプトップバイアルに入れ, 直ちにセプ タムキャップで密封する. 各バイアルを 5 分間室温 で静置後, SPMEファイバーをバイアルのヘッド スペースに20分間挿入し，続いてガスクロマトグラ フ質量分析装置の注入口に挿入， 1 分間脱離させ， SPME ファイバーに吸着した成分を分析した.

\section{2. 溶媒抽出法}

大麻草中の難揮発性成分の検出のため, 前処理方 法として，以下に示す溶媒抽出法を用いた。

3.1.で試験実施したバイアルを開封し，直ちにメ タノール溶液 $1 \mathrm{~mL}$ を添加し, デュラシールで密栓 する. 同バイアルの植物中の成分について15分間超 音波下抽出を行い, 抽出液を綿栓濾過後, ガスクロ マトグラフ質量分析装置用のマイクロバイアルに入 れ，ガスクロマトグラフィー/質量分析 (GC/MS) を行った。

\section{GC/MS}

下記の条件で大麻含有成分の測定を行った．

装置：Agilent Technologies 製 GC 7890B MS 5977A

注入法 : スプリットレス $(1.0 \mathrm{~min})$

カラム : Agilent Technologies 製 HP-5MS（長さ30 $\mathrm{m}$, 内径 $0.25 \mathrm{~mm}$, 膜厚 $0.25 \mu \mathrm{m}$ )

カラム温度 :

SPME 法 $50^{\circ} \mathrm{C}(1 \min$ 保持 $)-3{ }^{\circ} \mathrm{C} / \min -180^{\circ} \mathrm{C}$
(0.667 $\mathrm{min}$ 保持)（計45 $\mathrm{min}$ )

溶媒抽出法 $100^{\circ} \mathrm{C}-100^{\circ} \mathrm{C} / \mathrm{min}-130^{\circ} \mathrm{C}-3^{\circ} \mathrm{C} / \mathrm{min}-$ $300^{\circ} \mathrm{C}$ (3.033 $\mathrm{min}$ 保持) (計60 $\mathrm{min}$ )

注入口温度 : $260^{\circ} \mathrm{C}$

注入量 : $1 \mu \mathrm{L}$ （溶媒抽出法の久）

キャリアーガス流量 : $1.0 \mathrm{~mL} / \mathrm{min}(\mathrm{He})$ (Constant Flow)

トランスファーライン温度 : $280^{\circ} \mathrm{C}$

イオン化法: 電子イオン化

検出モード：Scan モード

スキャン範囲 : $m / z 40-650$

イオン源 : $230^{\circ} \mathrm{C}$

四重極温度 : $150^{\circ} \mathrm{C}$

イオン化エネルギー : $70 \mathrm{eV}$

ライブラリデータベース : NIST/EPA/NIH Mass

Spectral Database (NIST11) and NIST Mass Spectral Search Program (Version $2.0 \mathrm{~g}$ )

\section{5. デー夕解析}

GC/MS で得られたトータルイオン電流クロマト グラムのピーク面積值を解析対象とし, 栽培開始後 14日目から 5-7 日間ごとに 3 株の分析を行い，得ら れた結果の平均値を算出した。分析対象の選定は, 個体間の生長速度のばらつきを考慮し，色，葉数， 株の高さなど形態が類似しているものから選択し， 同じ株について測定日が連続しないように，測定日 ごとに対象株を入れ替えた。雄株は, 栽培開始後70 日目 (day70)，91日目（day91）打よび119日目 （day119）に分析を行った．そのため，雄株は葉の みを分析対象とし，Fig. 1，2b 及び $4 \mathrm{~b}$ にかかる花 穂のデータには含まれていない。

\section{6. 再現性について}

代表的な大麻の揮発性成分について，標準品を用 いて SPME 法にかかる精度を検討した。日内变動 は $\beta$-Myrcene (4.18\%), $\beta$-Ocimene (5.33\%)，

Terpinolene $(5.40 \%), \beta$-Caryophyllene $(8.51 \%)$, Humulene $(9.89 \%)$ であった。間変動は $\beta$-Myrcene $(3.67 \%), \beta$-Ocimene $(3.62 \%)$, Terpinolene $(3.30 \%), \quad \beta$-Caryophyllene $(4.40 \%)$, Humulene (7.43\%) であった.

代表的な大麻成分である THCについて，標準品 を用いて溶媒抽出法にかかる精度を検討したとこ 
ろ, 日内変動は $5.25 \%$, 日間変動 $5.09 \%$ であった。

\section{結 果}

1. SPME 法

SPME 法により大麻から50種類の揮発性成分を 検出した。（Table 1）なお，SPME 法における検出 限界（S/N 比は 3）は代表的な成分（Terpinolene, $\beta$-Caryophyllene) について, $20 \mathrm{~mL}$ 容バイアルへ の注入量として500 pg であった．テルペンの多く が，分子量136，154抢よび204で構成される異性体 であり，異性体の分離が課題であったが，長さ30 $\mathrm{m}$ の微極性カラムを使用し, 昇温条件を低温から 徐々に昇温させることで分離可能であった.

当該分析法により検出された揮発性成分のうち， テルペンのピーク面積值を，栽培期間に対してプロ
ットした結果をFig. 1 に示す. 葉から検出された テルペンのピーク面積值の合計（総テルペン）は， 生長が進むにつれて増加傾向を示すが, day49 以降 に入ると減少傾向を示した. 花穂から検出された総 テルペンは, 開花が進むにつれて増加傾向を示す が，day112を過ぎると減少傾向を示した。 また， 葉抢よび花穗から検出された総テルペン量を比較し た結果，いずれの時期においても花穂の方が多かっ た (Fig. 1).

さらに，葉および花穂から検出されたテルペンを モノテルペンおよびセスキテルペンに分類し，Fig. 1 と同様にプロットした結果を Fig. 2 に示す. 葉か らは，セスキテルペンの割合が強く，花穗からは， モノテルペンの割合が強く検出される傾向にあるこ とが示された．また，経時的变化を見ると，葉から

Table 1 List of constituents detected by SPME of fresh cannabis plants.

\begin{tabular}{|c|c|c|c|c|c|c|c|c|c|}
\hline No. & Compound Name & $\begin{array}{l}\mathrm{RT} \\
(\mathrm{min})\end{array}$ & M.W. & Classification & No. & Compound Name & $\begin{array}{l}\mathrm{RT} \\
(\mathrm{min})\end{array}$ & M.W. & Classificatio \\
\hline 1 & $3-\mathrm{He}$ & 4.066 & 98 & $\mathrm{O}$ & 20 & $\alpha-Y$ & 25.893 & 204 & ene \\
\hline 2 & $3-\mathrm{Hex}$ & 5.286 & 100 & & r & & & 204 & \\
\hline 3 & Thujene & 7.353 & 136 & Monoterpe & 28 & $\alpha-\mathrm{Cu}$ & 26.084 & 204 & \\
\hline 4 & $\alpha$-Pin & 7.575 & 136 & Monoter & 29 & cis- $\alpha$-Bergamotene & 27.905 & 204 & iterpene \\
\hline 5 & Camp & 8.068 & 136 & Monote & 30 & $\beta-\mathrm{Ca}$ & 28.054 & 204 & pene \\
\hline 6 & $\beta$-Pinen & 9.073 & 136 & Monc & 31 & $\gamma$-Ele & 28.648 & 204 & pene \\
\hline 7 & $\beta-\mathrm{M}$ & 9.652 & 136 & Monc & 32 & trans- $\alpha$-Berg & 28.758 & 204 & pene \\
\hline 8 & $\alpha$-Phe & .121 & 136 & Mono & 33 & $\alpha$-Guaiene & 28.855 & 204 & pene \\
\hline 9 & 3-Hex & 10.283 & 142 & 0 & 34 & & & 204 & pene \\
\hline 10 & 3-Car & 10.349 & 136 & onot & 3. & Hur & & 204 & ene \\
\hline 11 & $\mathrm{p}-\mathrm{CJ}$ & .619 & 134 & Mon & 36 & $\beta$-Fa & 58 & 204 & pene \\
\hline 12 & $\Delta$ & 10.582 & 142 & & 37 & & 17 & 204 & pene \\
\hline 13 & $\alpha-\mathrm{Tel}$ & 10.933 & 136 & 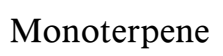 & $3 \varepsilon$ & 4.5 & 30 & 204 & sene \\
\hline 14 & D-Lir & 11.107 & 136 & & 3 & & & 204 & \\
\hline 15 & $\beta_{-} \mathrm{Pr}$ & 32 & 136 & & 40 & & & 204 & pene \\
\hline 16 & Euce & 99 & 154 & & 41 & & & 204 & pene \\
\hline 17 & trans- $\beta$ & 11.522 & 136 & & 42 & & & 204 & pene \\
\hline 18 & cis- $\beta-\mathrm{C}$ & & 136 & & 43 & & & 204 & ene \\
\hline 19 & $\gamma-\mathrm{Te}$ & 68 & 136 & $M$ & 44 & $\beta-\mathrm{B}$ & 16 & 204 & rpene \\
\hline 20 & Terp & 13.633 & 136 & & 45 & $\beta-\mathrm{Cu}$ & 31.832 & 204 & iterpene \\
\hline 21 & Lina & 14157 & 15 & & 46 & $\beta$-Ses & 32.283 & 204 & terpene \\
\hline 22 & Fenc & 14.712 & 154 & & 47 & & & 204 & erpene \\
\hline 23 & trans & 15.111 & 154 & & 48 & $\gamma-\mathrm{Eu}$ & 32.807 & 222 & iterpene \\
\hline 24 & Terpi & 17.561 & 154 & & 49 & Selina-3.7 (11 & 32.935 & 204 & Sesquiterpene \\
\hline 25 & $\alpha$-Terpineol ${ }^{*}$ & 18.157 & 154 & Monoterpene & 50 & $\alpha$-Bisabolene ${ }^{*}$ & 33.063 & 204 & Sesquiterpene \\
\hline
\end{tabular}

$[*]$ was specified based on the reference material, the others were estimated based on the library. 
検出されるモノテルペンおよびセスキテルペンは， ともに生長が進むにつれて増加傾向にあるが， day49を過ぎると減少傾向を示した（Fig. 2a). 花 穂から検出されるモノテルペンは開花が進むと増加 傾向を示すが, day112を過ぎると, 減少傾向を示 した (Fig. 2b).

当該分析法により，葉および花穂から検出される テルペンのピーク面積がピークに達した時点におけ る各成分の面積值の総和面積に対する百分率を比較 した結果（Fig. 3), 葉からは, セスキテルペンで

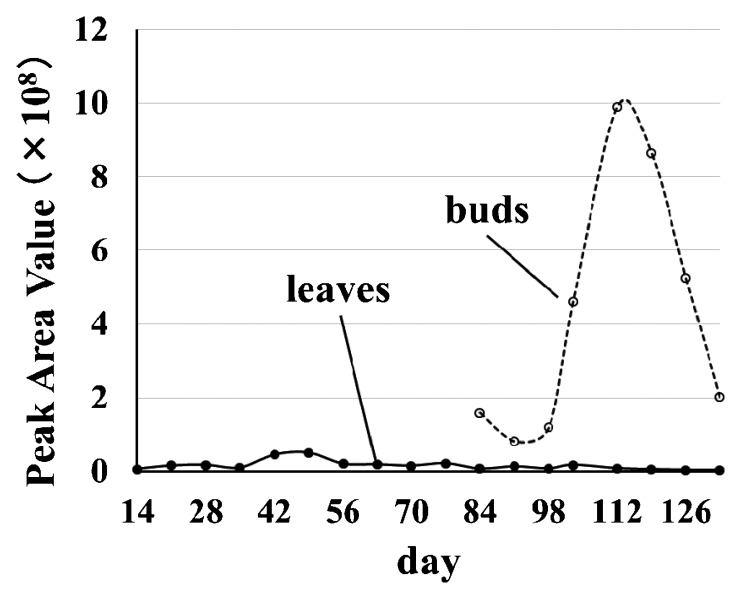

Fig. 1 Total peak areas of the terpenes in leaves and buds of grown cannabis plants, which underwent SPME.

(a)

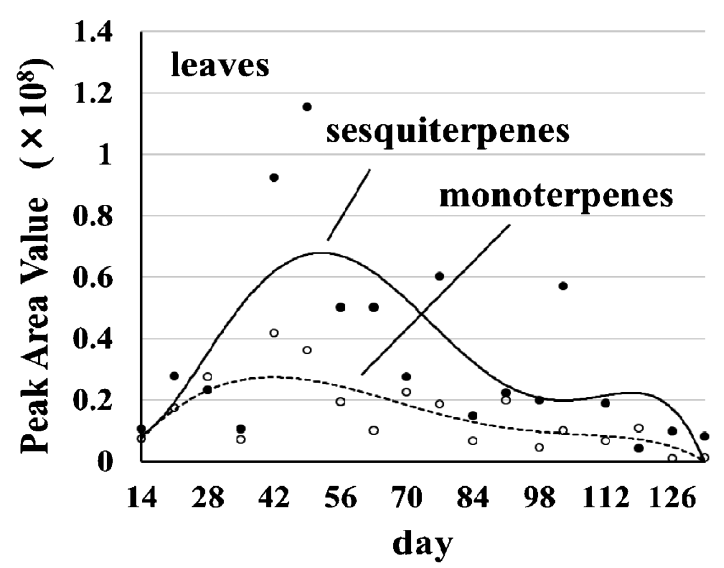

ある $\beta$-Caryophyllene および $\beta$-Farnesene などが強 く検出された．花穂からは，モノテルペンである $\beta$ -Myrcene, cis- $\beta$-Ocimene 抢よび Terpinolene が強 く検出された。なお，ピークトップはFig. 1 およ びFig. 2 の結果から，葉は day49時点，花穂は day112時点に設定した.

\section{2. 溶媒抽出法}

溶媒抽出法により大麻から 21 種類の難揮発性成分 を検出した（Table 2). なお，溶媒抽出法における 検出限界（S/N 比は 3) は代表的な成分（THC） について，ガスクロマトグラム質量分析装置への注 入量として1 ngであった. 全ての検体から検出さ れたカンナビノイドは $\mathrm{THC}, \mathrm{CBC}, \mathrm{CBG}$ および $\mathrm{THCV}$ であった．葉から検出される THC の経時的 な変化（Fig. 4a）は，概ね Fig. 2aのテルペンの変 化と酷似しており山型に変化していた。花穂から検 出される THC（Fig. 4b）は， day112を境に山型に 変化していた。

\section{考 察}

葉よりも花穗の方が検出できた揮発性成分の種類 が多く, 総テルペンの強度も強いことが確認され た。さらに, 葉はセスキテルペン, 花穂はモノテル ペンがより強く検出されることが確認された．分析 した大麻試料から強く検出された揮発性成分は,

(b)

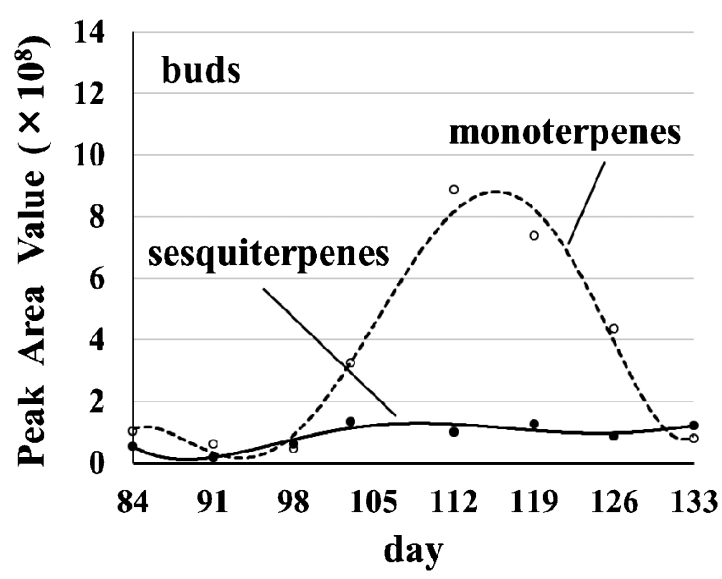

Fig. 2 Peak areas of monoterpenes and sesquiterpenes in cannabis leaves (a) and buds (b) that underwent SPME. 


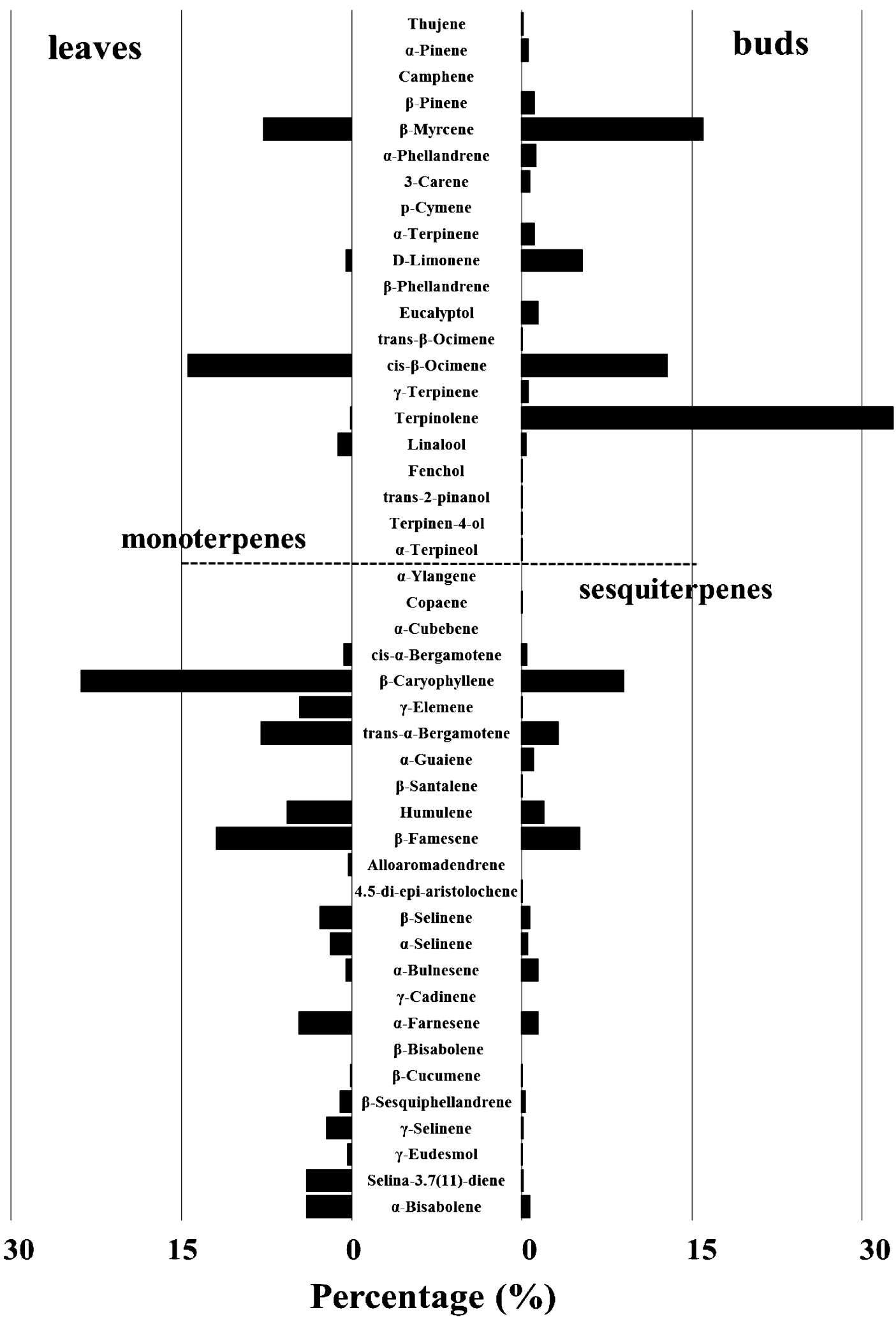

Fig. 3 Peak area ratios of terpenes that were SPME from cannabis leaves and cannabis buds. 
Table 2 List of constituents detected by solvent extraction of fresh cannabis plants.

\begin{tabular}{|c|c|c|c|c|c|c|c|c|c|}
\hline No. & Compound Name & $\begin{array}{l}\mathrm{RT} \\
(\mathrm{min})\end{array}$ & M.W. & Classification & No. & Compound Name & $\begin{array}{l}\mathrm{RT} \\
(\mathrm{min})\end{array}$ & M.W. & Classification \\
\hline 1 & $\alpha$-Bisabolol & 12.150 & 222 & Ses & 1 & Metl & 32 & 28 & \\
\hline 2 & $\begin{array}{l}\text { Palmitoleic acid } \\
\text { methyl ester }\end{array}$ & 19.051 & 270 & Fatt & 12 & $\begin{array}{l}\text { hydrocannabinol } \\
\text { Cannabidiol }(\mathrm{CBD}) *\end{array}$ & 33.085 & 314 & jinoid \\
\hline 3 & $\begin{array}{l}\text { Palmitic acid methyl } \\
\text { ester }\end{array}$ & 19.174 & 284 & id & 13 & $\begin{array}{l}\text { Cannabichromene } \\
(\mathrm{CBC})^{*}\end{array}$ & 33.555 & 314 & id \\
\hline 4 & $\begin{array}{l}\text { Linoleic acid methyl } \\
\text { ester }\end{array}$ & 24.142 & 294 & id & 14 & $\begin{array}{l}\text { Tetrahydrocan- } \\
\text { nabinol (THC)* }\end{array}$ & 35.777 & 314 & Cannabinoid \\
\hline 5 & Linolenic acid & 24.373 & 292 & atty & 15 & Cannabigerol $(\mathrm{CBG}) *$ & 37.171 & 316 & Cannabinoid \\
\hline & methy & & & & 16 & Cannabinol $(\mathrm{CBN})^{*}$ & 37.275 & 310 & Cannabinoid \\
\hline 6 & Oleic acid methyl ester & 24.471 & 296 & Fatty & 17 & Hexacosane & 44.659 & 366 & Hydrocarbon \\
\hline 7 & Phytol & 24.666 & 296 & Diterpene & 18 & Vitamin E & 49.546 & 430 & Vitamin \\
\hline 8 & Stearic acid methyl ester & 25.092 & 298 & Fatty acid & 19 & Campesterol & 51.194 & 400 & Phytosterol \\
\hline 9 & Cannabicitran (CBT) & 29.183 & 314 & Cannabinoid & 20 & Stigmasterol & 51.873 & 412 & Phytosterol \\
\hline 10 & $\begin{array}{l}\text { Tetrahydrocan- } \\
\text { nabivarin (THCV) }\end{array}$ & 30.270 & 286 & Cannabinoid & 21 & Sitosterol & 53.046 & 414 & Phytosterol \\
\hline
\end{tabular}

$[*]$ was specified based on the reference material, the others were estimated based on the library.

(a)

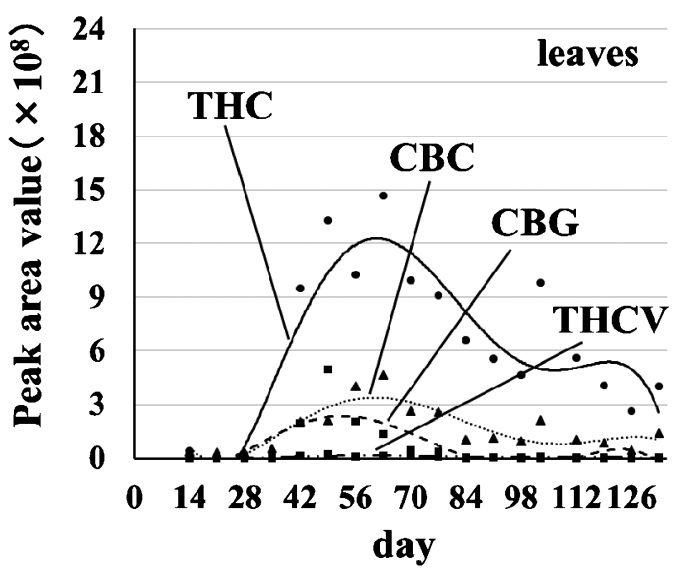

(b)

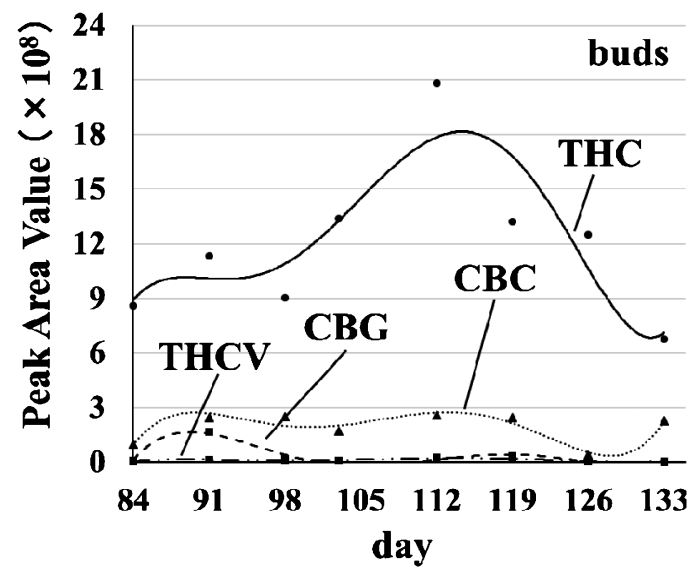

Fig. 4 Peak areas of THC, CBC, CBG and THCV in cannabis leaves (a) and buds (b) upon solvent extraction.

$\beta$-Myrcene, cis- $\beta$-Ocimene, Terpinolene, $\beta-$ Caryophyllene, trans $-\alpha$ Bergamotene, Humulene 抒 よび $\beta$-Farnesene であった. 大麻特有のカンナビノ イドである THC，CBC，CBG および THCV は溶 媒抽出法で得られた全ての試料から検出した.

テルペンおよびカンナビノイドの経時的変化につ いては，花穂の生成が開始された時期（day56前後 1 週間）を境に葉の成分含量が変化し（Fig. 2a お よびFig. 4a)，種子の生成が開始された時期 （day112前後 1 週間）を境に花穂の成分含量が変化 したと考えられる（Fig. 2b 抢よび Fig. 4b）.

溶媒抽出法で検出されたカンナビノイドは, 通常 大麻植物体内においてアシッド体として存在するこ とが一般的に知られているが，GC/MS の注入口で 脱炭酸反応し, THC, CBC, CBG, THCV として検 出されたと考えられる，また，脂肪酸のメチルエス テル体は, 大麻の抽出溶媒をメタノールからエタ ノールに変えた場合は未検出であり, カルボン酸体 
として検出されたことから，GC/MS の注入口また は試料調製時に溶媒のメタノールと反応し, GC/ MS で脂肪酸のメチルエステル体として検出された 可能性が考えられる (Table 2).

\section{1. 大麻製品の同定への利用可能性について}

Novak らは2001年に, 市販されている大麻精油 に多く含まれるテルペンは, $\alpha$-Pinene, $\beta$-Myrcene, $\beta$-Ocimene, Terpinolene, $\beta$-Caryophyllene および Humulene であり，モノテルペンが 63.97〜 73.11 \%, セスキテルペンは24.71〜33.18\%であり, モノ テルペンの方が多く含まれている結果を報告6)して いる. Fig. 2, Fig. 3 の結果に当てはめると, 本大 麻精油は, 開花期以降の大麻草の全草もしくは花穂 から精製されたものであると推定できる.

一方で，大麻精油に含まれる成分の大半はセスキ テルペンであったとする報告9,10) もある。これらの 報告は精油を直接分析し, 得られた結果である.

Hood らは，大麻精油を直接分析する方法とへッド スペース法を比較し，前者はセスキテルペンが多 く，後者はモノテルペンの方が多かったと報告5 し ている、ヘッドスペース法は，気相中に分布する揮 発性成分の組成を評価して抢り，精油を直接分析す る方法は，液相中の成分組成を評価するものであ る.モノテルペンは，特に揮散しやすい性質 ${ }^{13)}$ があ ることから気相中から検出されやすく, 一方で, セ スキテルペンは液相中から検出されやすい傾向にあ ると考えられる.

ヨーロッパ諸国で流通している大麻から製造され たCBD オイルには， $\beta$-Myrcene, cis- $\beta$-Ocimene, Terpinolene, $\beta$-Caryophyllene, $\alpha$-Bergamotene 抢よ び Humulene がほとんぞの検体から検出されてい る.さらに，大麻特有のカンナビノイドである CBG またはそのアシッド体が，全ての試料から検 出されている14)。本研究結果は, 既報15)の内容を支 持した。

大麻製品の中には, THC 含有が多い花穂からブ

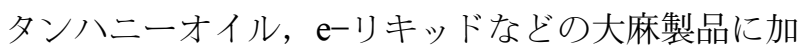
工された物や，それ以外の部位から大麻成分を抽出 し, 加工された物が存在する. 新鮮な大麻草の生長 段階や葉，花穂の部位を問わず，多くの揮発性成分 やカンナビノイドを検出したという結果は，様々な
大麻製品の鑑定への応用が期待され, 複数の揮発性 成分およびカンナビノイドを分析することで，合成 THC との鑑別に有用であると考えられる．大麻製 品の鑑定に際し, 複数の揮発性成分を調べる場合 は, $\beta$-Myrcene, cis- $\beta$-Ocimene, Terpinolene, $\beta$ Caryophyllene, trans $-\alpha-$ Bergamotene, Humulene 打 よび $\beta$-Farnesene など大麻草から多く検出された成 分がターゲットにしやすいと考えられる.

揮発性成分はどれも大麻特有のものではないが， 大麻製品が化学合成により作られたものではなく, 植物由来製品であることを立証するための重要な因 子となり得る.

ただし，大麻製品の中には，製品そのものが古い 物や加熱条件下で加工されたものであった場合は, 揮発性成分が検出されにくい。これは, 揮発性成分 が揮散しやすい性質によるものであり, 長期保存に よる自然拡散抢よび加熱処理による熱拡散が認めら れる場合は検出が難しいと考えられる.

本研究で用いた SPME 法の利点は, 目的成分の 吸着濃縮ができ, かつ大麻製品中に含まれる脂質や 糖類などの夾雑物質の影響を除外し, 溶媒抽出法よ りもクロマトグラムのベースラインを低下すること ができることから揮発性成分の高感度分析が可能で あることにある。

\section{2. 大麻栽培事犯の捜査への利用可能性について}

大麻草から検出される揮発性成分は, 生長過程に よって検出強度の变化や検出成分の種類の变化など 特徵的な挙動を示している（Fig. 1，Fig. 2(a) およ びFig. 2(b)）ことから, 大麻草の栽培の有無や大 麻草の生長段階の推定ができ, 大麻栽培事犯の捜査 に利用できると考えられる。 $\beta$-Myrcene, cis- $\beta-$ Ocimene, Terpinolene, $\beta$-Caryophyllene, trans $-\alpha$-Bergamotene, Humulene 抢よび $\beta$-Farnesene など大麻 草から多く検出された成分がターゲットにしやすい と考えられる．揮発性成分はどれも大麻特有のもの ではないが, 複数の成分を対象とすることで, 推定 は可能であると考えられた。

\section{3. 今後の展望について}

本研究で得られた結果を鑑定法に一般化するため には, 今後複数の起源の大麻草を対象とした比較検 討が必要である。 
実際に，大麻製品を分析した事例は少ないことか ら, 今後は実際に出回っている大麻製品について分 析していく方針である.オイル製品から食品などの あらゆる大麻製品の流入が想定されることから揮発 性成分やカンナビノイドが検出できる最適条件を調 ベていきたいと考えている.

本研究では, 試料を直接バイアル内に入れ, SPME でヘッドスペースの揮発性成分を吸着させ て分析したものであるが，更なる検討により，実際 の栽培現場におけるにおい分析に応用が期待でき る.

\section{結 語}

SPME 法により, モノテルペンの $\beta$-Myrcene, cis - $\beta$-Ocimene およびTerpinolene, セスキテルペン の $\beta$-Caryophyllene, trans $-\alpha-$ Bergamotene, Humulene および $\beta$-Farnesene が強く検出され, 溶媒抽出 法により，全ての検体から THC， CBC， CBG お よびTHCV が検出された。これらの揮発性成分お よびカンナビノイドの組み合わせが大麻製品の同定 において有望なターゲットであると考えられた。 た，これらの揮発性成分は大麻栽培事犯の捜査へ応 用できる可能性があると考えられた。

\section{文献}

1）厚生労働省医薬生活衛生局監視指導麻薬対策 課, 不正薬物の取締, 麻薬 - 覚醒剂行政の概況 (2017), pp. 79-176, 厚生労働省, 東京, 2017.

2) Stahl E. and Kunde R., Dile Leitsubstanzen der Haschisch-Suchhunde. Kriminalistik: Z Gesamte Kriminal Wiss Prax, 27(9), 385-388, 1973.

3）岩田祐子, 金森達之, 宮口一, 辻川健治, 桑山健次, 山室匡史, 瀬川尋貴, 井上博之, に おい検知を指向した大麻揮発性成分のキャラク タリゼーション, 科警研報告, $66(1), 1-10$, 2017.

4) Wiebelhaus N., Hamblin D., Kreitals N. M. and Almirall J. R., Differentiation of marijuana headspace volatiles from other plants and hemp products using capillary microextraction of volatiles (CMV) coupled to gas-chromatography- mass spectrometry (GC-MS). Forensic Chemistry, 2, 1-8, 2016.

5) Hood L. V. S., Dames M. E. and Barry G. T., Headspace volatiles of marijuana. Nature, 242 (5397), 402-403, 1973.

6) Novak J., Zitterl-Eglseer K., Deans S. G. and Franz C. M., Essential oils of different cultivars of Cannabis sativa L. and their antimicrobial activity. Flavour Fragr. J., 16, 259-262, 2001.

7) Rice S. and Koziel J. A., Characterizing the smell of marijuana by odor impact of volatile compounds: An application of simultaneous chemical and sensory analysis. PLoS ONE, 10 (12), doi:10.1371/journal.pone.0144160, 2015.

8) Ross S. A. and ElSohly M. A., The volatile oils composition of fresh and air-dried buds Cannabis sativa. J Nat Prod, 59(1), 49-51, 1996.

9) Hendriks H., Malingre T. M., Batterman S. and Bos R., Mono- and sesqui-terpene of the essential oils of Cannabis sativa. Phytochemistry, 14(3), 814-815, 1975.

10) Nigam M. C., Handa K. L., Nigam I. C. and Levi L., The essential oil of marifuana: Composition of genuine indian Cannabis sativa L. Can. J. Chem, 43, 3372-3376, 1965.

11) Aizpurua-Olaizola O., Soydaner U., Ozturk E., Schibano D., Simsir Y., Navarro P., Etxebarria N. and Usobiaga A., Evolution of the Cannabinoid and Terpene content during the growth of Cannabis sativa plants from different chemotypes. J Nat Prod, 79, 324-331, 2016.

12）マリファナ・X 編集会, マリファナ・X一意 識を変える草が世界を変える一。第12刷, pp. 320-413，北川明，東京，2008.

13) World Health Organization, WHO Expert Committee on Drug Dependence Pre-Review, Cannabis plant and cannabis resin, Section 1: Chemistry, Switzerland, 2018.

14) Pavlovic R., Nenna G., Calvi L., Panseri S., Borgonovo G., Giupponi L., Cannazza G. and Giorgi A., Quality Traits of "Cannabidiol Oils": 
Cannabinoids Content, Terpene Fingerprint and Oxidation Stability of European Commercially
Available Preparations. Molecules, 23(5), 1230, 2018. 